
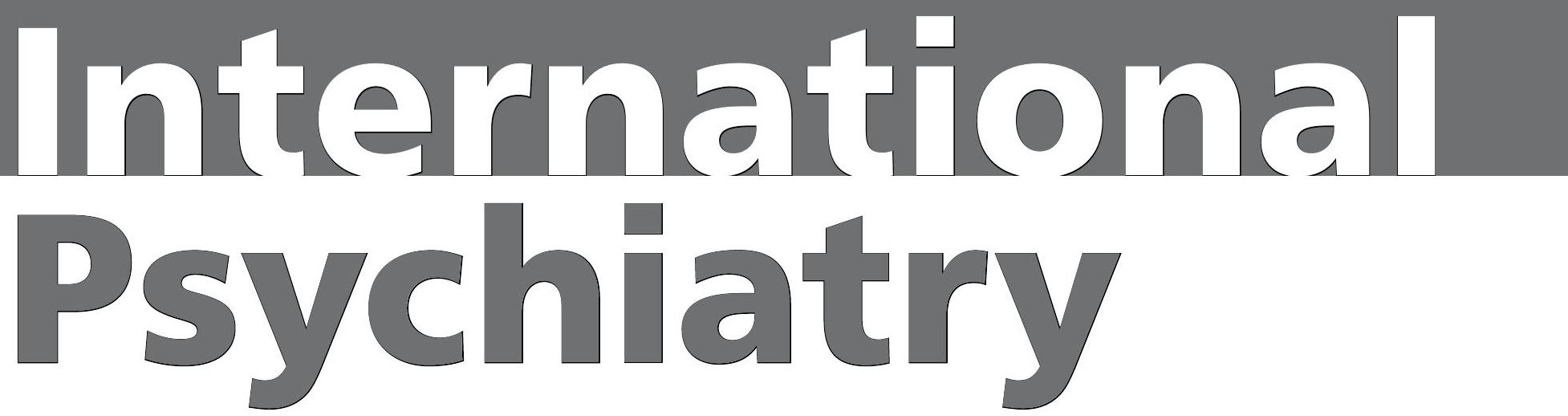

Editorial

Smoking and mental health

Hamid Ghodse

Thematic papers - The mental health of refugees

Introduction

David Skuse

Refugee mental health challenges in Africa

Frank G. Njenga

Sudanese refugees: sufferings and suggested management

Nasser Loza and Nael Hasan

Post-traumatic stress disorder among Afghan refugees following war

Khalid A. Mufti, Farooq Naeem, Haroon Rasheed Chaudry, Asad Haroon, Farida Saifi,

Siama Mahmood Qureshi and Saif ur Rehman Dagarwal

\title{
Country profiles
}

Malawi

Felix Kauye and Chitsanzo Mafuta

Mental health and psychiatry in Thailand

Pichet Udomratn

Lebanon

F. Antun, Charles Baddoura and Mounir Khani

\section{Special papers}

Reform of the mental healthcare system in Greece, 1984-2006

Michael G. Madianos and George N. Christodoulou

Attitudes towards mental illness in Uganda: a survey in 18 districts

Vuokko Wallace, Jed Boardman and James Walsh

\section{Point of view}

Doctors' values, resilience and professionalism

Richard Williams

News and notes

Correspondence

Forthcoming international events 


\section{Editor}

Professor Hamid Ghodse

\section{Editorial board}

Dr John Henderson

Mr Robert Jackson

Professor Rachel Jenkins

Dr Nasser Loza

Dr Brian Martindale

Dr Shekhar Saxena

Professor David Skuse

\section{Subscriptions}

International Psychiatry is published four times a year.

Non-members of the College should contact the Publications Subscriptions Department, Maney Publishing,

Suite 1C, Joseph's Well, Hanover Walk, Leeds LS3 1AB, UK

tel. +44 (0)113243 2800; fax +44 (0)113 386 8178; email: subscriptions@maney.co.uk

For subscriptions in North America please contact: Maney Publishing North America, 875 Massachusetts Avenue,

7th Floor, Cambridge, MA 02139, USA

tel. 8662975154 (toll free); fax 617354 6875; email: maney@maneyusa.com

Annual subscription rates for 2007 (four issues, post free) are $£ 25.00$ (US\$45.00).

Single issues are $\mathrm{f} 8.00$ (US\$14.40), post free.

\section{Contributions for future issues are welcome. Please contact Hamid Ghodse, email: hghodse@sgul.ac.uk}

International Psychiatry was originally published as (and subtitled) the Bulletin of the Board of International Affairs of the Royal College of Psychiatrists.

Design (c) The Royal College of Psychiatrists 2007.

For copyright enquiries, please contact the Head of Publications, Royal College of Psychiatrists.

All rights reserved. No part of this publication may be reprinted or reproduced or utilised in any form or by any electronic, mechanical or other means, now known or hereafter invented, including photocopying and recording, or in any information storage or retrieval system, without permission in writing from the publishers.

The views presented in this publication do not necessarily reflect those of the Royal College of Psychiatrists, and the publishers are not responsible for any error of omission or fact.

The Royal College of Psychiatrists is a registered charity (no. 228636).

Printed in the UK by Henry Ling Limited at the Dorset Press, Dorchester DT1 1 HD.

\section{US mailing information}

International Psychiatry is published quarterly by the Royal College of Psychiatrists. Subscription price is $\$ 45$. Second class postage paid at Rahway, NJ. Postmaster send address corrections to International Psychiatry, c/o Mercury International, 365 Blair Road, Avenel, New Jersey 07001.

TMThe paper used in this publication meets the minimum requirements for the American National Standard for Information Sciences Permanence of Paper for Printed Library Materials, ANSI Z39.48-1984. 